\title{
ANALISIS COST OF ILLNESS PENYAKIT HIPERTENSI DI RUMAH SAKIT UMUM DAERAH PRAYA, NTB
}

\author{
Aris Fadillah*1), Juwita Ramadhani ${ }^{1)}$, Karina Erlianti' ${ }^{1)}$, dan Hasniah ${ }^{1)}$ \\ ${ }^{I}$ Fakultas Ilmu Farmasi Universitas Islam Kalimantan Muhammad Arsyad Al Banjari Banjarmasin, \\ Kalimantan Selatan \\ *Email: aris.f.1993@gmail.com
}

\begin{abstract}
The high prevalence of hypertension and the long-term of antihypertensive treatments required are the main reasons for the need of economic analysis on the costs of hypertensive treatment. This study aims to quantify direct medical cost of hypertension. This study uses retrospective cost of illness analysis in descriptive observational design with heath care perspective. Data were collected from the hospital's management information system, patient's prescriptions and patient's medical records. Fifty-eight patient's data were analyzed. Direct medical cost of the patient without comorbidities in stage 1 hypertension was Rp 535,660 $\pm 100,681$, stage 2 hypertension was Rp 381,940 $\pm 126,423$ and hypertensive crises was Rp 456,241 $\pm 197,959$. Direct medical cost of the patients with comorbidities in stage 1 hypertension was Rp 398,750 \pm 240,542, stage 2 hypertension was $R p 486,227 \pm 241,136$ and hypertensive crises was $\mathrm{Rp} 425,816 \pm$ 140,898 . Direct medical costs for patients with compelling indications in stage 1 hypertension was $\mathrm{Rp}$ $512,810 \pm 152,661$, stage 2 hypertension was Rp 444,183 $\pm 109,162$ and hypertensive crises was Rp 410,364 $\pm 80,388$. Cost for drugs was represented as the largest component of direct medical cost $(37.49 \%)$ followes by cost for ward $(26.54 \%)$, medical treatment fee $(15.88 \%)$, medical support fee $(9.05 \%)$, doctor visit fee $(8.12 \%)$ and service fee $(2.91 \%)$. The hypertension's stage, comorbidities and compelling indications are not affecting the cost of therapy. The rational use of drugs will decrease the cost of hypertension treatment.
\end{abstract}

Keywords: cost of illness, direct medical cost, hypertension

\section{PENDAHULUAN}

Evaluasi ekonomi sudah berkembang menjadi bagian penting dalam bidang pelayanan kesehatan. Evaluasi ekonomi memegang peranan yang signifikan dalam proses pengambilan keputusan (Drummond et al., 2005). Fasilitas kesehatan yang melakukan pelayanan pada pasien peserta BPJS kesehatan perlu membuat kebijakan-kebijakan yang tepat dalam mengalokasikan dana perawatan pasien, agar dana tersebut dapat mencakup semua biaya yang diperlukan selama perawatan. Salah satu komponen biaya yang dapat ditekan adalah biaya obat. Data hasil analisis farmakoekonomi sangat diperlukan dalam pengambilan keputusan yang lebih rasional dalam proses pemilihan strategi terapi, pengobatan, maupun alokasi sumber daya yang tersedia (Tjandrawinata, 2016).

Analisis cost of illness (COI) dilakukan dengan menyajikan data biaya keseluruhan yang dikeluarkan dalam pengobatan suatu penyakit tanpa dilakukan perbandingan rasio dengan efektivitasnya. Data analisis COI dapat memberikan informasi yang penting untuk analisis farmakoekonomi lainnya dalam memperkirakan biaya suatu penyakit yang ingin diteliti lebih lanjut (Andayani, 2013).

Hipertensi yang tidak terkontrol merupakan faktor risiko utama terjadinya penyakit kardiovaskuler yang merupakan penyebab utama kematian di seluruh dunia (Benjamin et al., 2017). Data Riset Kesehatan Dasar tahun 2018 menunjukkan bahwa prevalensi hipertensi pada penduduk Indonesia usia 18 tahun keatas adalah sebesar $34,1 \%$ dan pada provinsi Nusa Tenggara Barat (NTB) sendiri sebesar 27,80\%. Kabupaten Lombok Tengah merupakan kabupaten dengan prevalensi hipertensi terbanyak kedua di NTB dengan prevalensi sebesar 29,00\% (Kemenkes RI, 2019). 
Tingginya prevalensi hipertensi yang tidak terkontrol disebabkan oleh kurangnya kepatuhan minum obat di kabupaten Lombok Tengah. Proporsi penduduk kabupaten Lombok Tengah yang tidak rutin minum obat anti hipertensi merupakan yang terbesar di provinsi NTB yaitu $51,11 \%$ dan pasien yang tidak minum obat sebesar $9,81 \%$, salah satu alasan tidak minum obat rutin adalah tidak mampu membeli obat rutin (19.89\%) sehingga perlu dilakukan evaluasi biaya medis sebagai dasar untuk menentukan efisiensi biaya terapi (Kemenkes RI, 2019).

Rumah sakit umum daerah (RSUD) Praya adalah rumah sakit pemerintah daerah yang merupakan pusat rujukan tingkat lanjut bagi fasilitas kesehatan tingkat pertama di Kabupaten Lombok Tengah. RSUD Praya ditunjuk sebagai sarana rujukan yang mendukung destinasi wisata Mandalika Resort. Berdasarkan data profil RSUD Praya, terjadi peningkatan pengeluaran belanja obat dan bahan medis habis pakai dibandingkan dengan tahun sebelumnya yaitu dari Rp. 9.500.000.000 menjadi Rp. 13.200.000.000. Namun peningkatan anggaran ini tidak diikuti dengan peningkatan indikator pelayanan rawat inap secara signifikan (RSUD Praya, 2016). Hal ini kemungkinan disebabkan oleh beberapa faktor, salah satunya adalah belanja obat yang tidak efisien akibat tidak adanya pedoman formularium rumah sakit. Data hasil analisis farmakoekonomi diperlukan untuk mengetahui proporsi komponen biaya dalam terapi serta gambaran biaya yang dikeluarkan untuk terapi suatu penyakit. Data ini dapat juga dijadikan sebagai bahan evaluasi untuk mengetahui kerasionalan penggunaan obat di rumah sakit.

Tujuan utama terapi hipertensi adalah menurunkan angka mortalitas dan morbiditas dari penyakit kardiovaskuler dan renal. Tekanan darah (TD) yang terkontrol dengan baik akan mengurangi risiko terjadinya stroke (35-40\%), infark miokard (20-25\%) dan gagal jantung (>50\%) (Joint National Committee, 2004). Pemilihan terapi harus sesuai dengan pedoman yang dibuat berdasarkan hasil penelitian (evidence-based). Pertimbangan lain dalam pemilihan terapi adalah biaya. Faktor biaya akan menambah beban ekonomi pada negara berkembang. Rendahnya pendapatan perkapita masyarakat dan kurangnya ketersediaan asuransi kesehatan menjadi penyebab ketidaksesuaian pemilihan terapi dengan pedoman yang sudah ditetapkan (Amira dan Okubadejo, 2006)

Tujuan dari penelitian ini adalah (1) untuk mengetahui komponen biaya medis langsung pada penyakit hipertensi yang paling dominan, (2) untuk mengetahui biaya medis langsung pada penyakit hipertensi berdasarkan diagnosa pasien tanpa penyakit penyerta, dengan penyakit penyerta, dan dengan penyakit penyulit. Analisis dilakukan menggunakan metode cost of illness dengan perspektif fasilitas kesehatan.

\section{METODE PENELITIAN}

\section{Penetapan Populasi}

Populasi target dalam penelitian ini adalah semua data pasien rawat inap di RSUDD Praya tahun 2016. Populasi terjangkau adalah data pasien yang dirawat inap di RSUD Praya periode JanuariDesember tahun 2016. Penelitian ini menggunakan semua populasi terjangkau sebagai subjek.

\section{Kriteria Inklusi dan Eksklusi}

Kriteria inklusi dalam penelitian ini adalah pasien RSUD Praya dengan diagnosis utama hipertensi; pasien usia di atas 18 tahun; tidak dalam keadaan hamil; bukan pasien dengan kanker atau terinfeksi human immunodeficiency virus (HIV); bukan pasien yang keluar rumah sakit dengan keterangan pulang paksa, dirujuk atau meninggal dunia. Kriteria eksklusi dalam penelitian ini adalah pasien dengan data kurang lengkap, hilang atau tidak terbaca.

\section{Pengumpulan dan Seleksi Data Pasien}

Data pasien yang diambil merupakan data sekunder dari sistem informasi manajemen rumah sakit (SIMRS), resep di instalasi farmasi dan rekam medis pasien. Data yang diambil yaitu data identitas pasien (nomor rekam medis, nama, usia, jenis kelamin, alamat, tanggal masuk dan keluar rumah sakit, lama rawat inap, ruang dan kelas perawatan, jaminan kesehatan, keterangan keluar rumah sakit, diagnosis utama, penyakit penyerta, biaya medis langsung (biaya obat antihipertensi, obat lainnya, ruang perawatan, kunjungan dokter, tindakan, 
penunjang, dan pelayanan lain). Data pasien diseleksi sesuai dengan kriteria inklusi dan eksklusi.

\section{Analisis Data Pasien}

Analisis cost of illness dengan desain observasional deskriptif dilakukan secara retrospektif dengan sudut pandang rumah sakit untuk membandingkan biaya dan outcome obat antihipertensi yang digunakan di RSUD Praya.

Data pasien dikelompokkan berdasarkan ada tidaknya penyakit penyerta dan stage hipertensi. Klasifikasi stage hipertesi ditentukan berdasarkan tekanan darah menurut pedoman JNC 7 dengan sedikit penyesuaian. Pedoman ini juga digunakan sebagai dasar penentuan keparahan hipertensi di Indonesia. Semakin tinggi stage hipertensi, semakin banyak pula terapi yang diperlukan. Hipertensi stage I dengan range tekanan darah 140-159/90-99 mmHg, hipertensi stage II 160-179/100-109 mmHg dan hipertensi krisis $>180 / 110 \mathrm{mmHg}$ (Joint National Committee, 2004). Biaya medis langsung ditampilkan dalam satuan rata-rata per hari dan standar deviasinya.

\section{HASIL DAN PEMBAHASAN}

\section{Karakteristik Pasien}

Sebanyak 155 data pasien memenuhi kriteria inklusi, tetapi hanya 58 data pasien yang tidak tereksklusi dan menjadi subjek penelitian (Gambar 1).

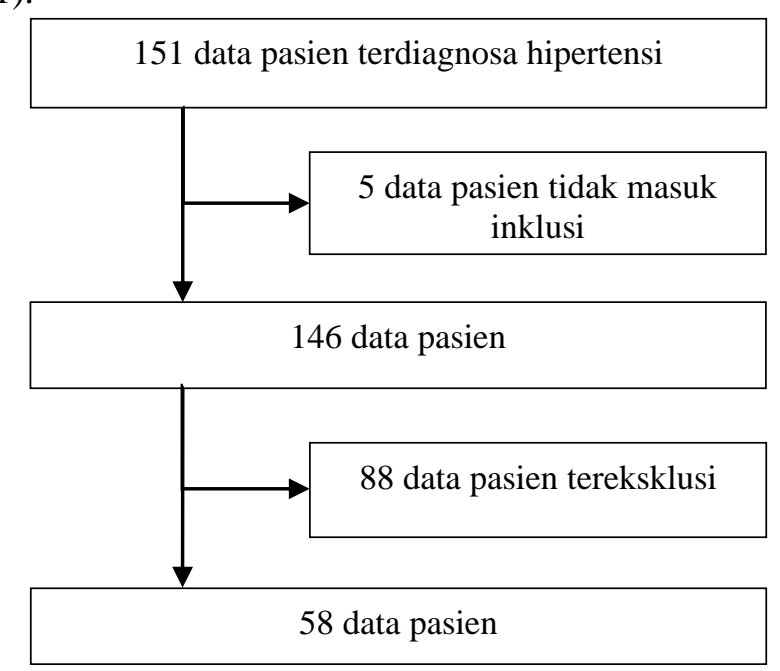

Gambar 1. Seleksi data pasien secara skematik

Pasien hipertensi didominasi oleh pasien perempuan sebanyak 37 pasien atau 63,79\% (Tabel
1). Hal ini sesuai dengan hasil studi prevalensi hipertensi secara global yang dilakukan pada tahun 2004 (Kearney et al., 2004) dan data profil kesehatan Indonesia tahun 2018 (Kemenkes RI, 2019) serta beberapa penelitian tentang hipertensi sebelumnya (Athanasakis et al., 2014; Rustiani et al., 2014; Wijayanti et al., 2014) yang menunjukkan bahwa prevalensi penyakit hipertensi lebih banyak terjadi pada perempuan. Hal ini dapat disebabkan oleh beberapa kondisi seperti post-menopouse, penggunaan kontrasepsi oral, maupun penigkatan aktivitas renin-angiotensin system (RAS) pada perempuan (Gudmundsdottir et al., 2012; Hage et al., 2013).

Tabel 1. Karakteristik subjek penelitian

\begin{tabular}{lcc}
\hline Karakteristik & $\mathbf{N}$ & $\mathbf{\%}$ \\
\hline Jenis kelamin $(\mathrm{N}=58)$ & & \\
\hline Laki-laki & 21 & 36,21 \\
Perempuan & 37 & 63,79 \\
\hline Kelompok usia (N= 58) & & \\
\hline 18-44 tahun & 4 & 6,9 \\
45-54 tahun & 10 & 17,24 \\
55-64 tahun & 28 & 48,28 \\
65-74 tahun & 12 & 20,69 \\
$\geq 75$ tahun & 4 & 6,9 \\
\hline Stage penyakit hipertensi $(\mathrm{N}=58)$ & \\
\hline Stage 1 & 15 & 25,86 \\
Stage 2 & 26 & 44,83 \\
\hline Krisis & 17 & 29,31 \\
\hline Penyakit penyerta $(\mathrm{N}=58)$ & & \\
\hline Tanpa penyerta & 13 & 22,41 \\
Diabetes mellitus & 11 & 18,97 \\
Vertigo & 8 & 13,79 \\
\hline Stroke iskemik & 6 & 10,34 \\
\hline Dispepsia & 4 & 6,90 \\
Epitaksis & 3 & 5,17 \\
Lain-lain* & 15 & 25,86 \\
\hline Keterngan & &
\end{tabular}

Keterangan: $n$, jumlah pasien

*penyakit penyerta meliputi: anemia, gastritis, gastroenteritis akut, ST elevation miocard infarction, transient ischemic attack (masing-masing 3,45\%); congestive heart failure, chronic kidney disease, infeksi saluran kemih, non-ST elevation miocard infarction, systemic lupus erythematosus (masingmasing $1,72 \%)$. 
Jumlah penderita hipertensi meningkat pada kelompok usia di atas 45 tahun dan jumlah kasus terbanyak adalah pada kelompok usia 55-64 tahun yaitu sebanyak 28 pasien atau 48,28\% (Tabel 1). Hal ini sesuai dengan data profil kesehatan Indonesia tahun 2018 yang menunjukkan prevalensi penyakit hipertensi lebih banyak terjadi pada usia 45 tahun ke atas (Kemenkes RI, 2019). Tekanan darah akan semakin tinggi seiring bertambahnya usia, disebabkan oleh terjadinya perubahan struktur dinding pembuluh darah yang menyebabkan elastisitasnya menurun yang mengakibatkan tekanan darah meningkat (Rahajeng dan Tuminah, 2009; Setianto et al., 2021). Selain itu rendahnya tingkat pendidikan pada penduduk lanjut usia juga nerupakan salah satu faktor pemicu tingginya prevalensi, dibuktikan dengan hasil riset kesehatan dasar provinsi NTB tahun 2018 dimana prevalensi tertinggi $(50,42 \%)$ terjadi pada penduduk yang tidak atau belum pernah sekolah.

Diagnosa hipertensi terbanyak adalah hipertensi stage II yaitu sebanyak 26 pasien (Tabel 1). Hal ini akan mempengaruhi pola penggunaan obat antihipertensi di rumah sakit tersebut. Berdasarkan pedoman hipertensi yang disusun pada JNC 7 direkomendasikan penggunaan terapi tunggal untuk pasien hipertensi stage 1 dan kombinasi terapi pada pasien hipertensi stage 2 dan hipertensi krisis. Kombinasi terapi artinya penggunaan lebih dari satu jenis obat. Pada pasien dengan diagnosis hipertensi stage II direkomendasikan penggunaan kombinasi antihipertensi agar target tekanan darah dapat tercapai secara optimal (Soenarta et al., 2015; Whelton et al., 2017). Adapun obat-obat yang digunakan dalam kombinasi terapi sudah ditentukan di pedoman JNC 7.

Sebagian besar pasien hipertensi memiliki penyakit penyerta lain (45 pasien). Pasien hipertensi dengan diabetes mellitus (DM) merupakan yang terbanyak dalam kelompok pasien dengan penyakit penyerta yaitu (11 pasien). Resiko terjadinya hipertensi cenderung lebih tinggi pada penderita DM dan sebaliknya. Mekanisme patofisiologi hipertensi yang berhubungan dengan DM sangatlah kompleks. Mekanisme yang paling umum adalah terjadinya aktivitas Renin-Angiotensin-Aldosteron System (RAAS). Aktivitas RAAS akan meningkatkan tekanan darah sehingga menyebabkan hipertensi serta dapat meningkatkan ekskresi reactive oxygen species (ROS) yang akan menimbulkan resistensi insulin yang merupakan penyebab penyakit DM (Sampanis dan Zambounis, 2008; Lastra et al 2014).

\section{Analisis Cost of Illness}

Analisis cost of illness (COI) dilakukan dengan menyajikan data biaya langsung medis tiap kelompok pasien. Biaya medis langsung dalam penelitian ini meliputi biaya antihipertensi, obat lain, ruang perawatan, kunjungan dokter, tindakan, penunjang, dan pelayanan lain. Data dikelompokkan berdasarkan diagnosis utama dan penyakit penyerta. Data analisis COI dapat dilihat pada Tabel 2.

Rata-rata total biaya langsung medis pada kelompok pasien tanpa penyakit penyerta dengan diagnosis hipertensi stage 1 sebesar Rp $535.660 \pm$ 100.681, hipertensi stage 2 sebesar Rp $381.940 \pm$ 126.423 dan hipertensi krisis sebesar Rp $456.241 \pm$ 197.959. Biaya medis langsung kelompok hipertensi stage 1 lebih tinggi dibandingkan dengan kelompok lainnya pada pasien tanpa penyakit penyerta meskipun perbedaan tersebut tidak signifikan secara statistik. Hal ini dapat disebabkan pasien pada kelompok hipertensi stage 1 memiliki penyakit penyerta atau penyulit namun tidak tercatat di rekam medis. Hal ini dapat dilihat dari biaya obat lain serta biaya penunjang yang tinggi jika dibandingkan dengan kelompok lainnya.

Rata-rata total biaya langsung medis pada kelompok pasien dengan penyakit penyerta dengan diagnosis hipertensi stage 1 sebesar Rp $398.750 \pm$ 240.542, hipertensi stage 2 sebesar $\mathrm{Rp} 486.227 \pm$ 241.136 dan hipertensi krisis sebesar Rp $425.816 \pm$ 140.898. Biaya medis langsung antara kelompok pasien dengan penyakit penyerta tidak memiliki perbedaan yang signifikan. Secara umum, biaya obat lain pada kelompok pasien dengan penyakit penyerta lebih tinggi dibandingkan dengan kelompok pasien tanpa penyakit penyerta. Hal ini disebabkan kelompok pasien tersebut memerlukan obat-obatan lain untuk mengatasi penyakit penyerta selain hipertensi sehingga biaya obat menjadi semakin tinggi.

Rata-rata total biaya langsung medis pada kelompok pasien dengan penyakit penyulit dengan diagnosis hipertensi stage 1 sebesar Rp $512.810 \pm$ 
Tabel 2. Analisis cost of illness terapi hipertensi pasien rawat inap RSUD Praya tahun 2016

Biaya Langsung Medis Pasien per-Hari (Rata-rata \pm SD)

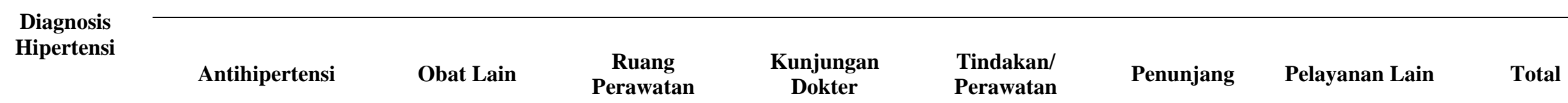

\begin{tabular}{|c|c|c|c|c|c|c|c|c|}
\hline \multicolumn{9}{|c|}{ Tanpa Penyakit Penyerta } \\
\hline HT stage 1 & $11.388 \pm 13.265$ & $172.383 \pm 73.742$ & $136.667 \pm 11.547$ & $33.611 \pm 6.255$ & $66.389 \pm 2.393$ & $106.056 \pm 45.824$ & $9.167 \pm 5.204$ & $535.660 \pm 100.681$ \\
\hline HT stage 2 & $21.821 \pm 23.721$ & $114.343 \pm 79.366$ & $126.933 \pm 63.511$ & $39.500 \pm 10.062$ & $51.675 \pm 11.539$ & $10.333 \pm 13.367$ & $17.333 \pm 18.878$ & $381.940 \pm 126.423$ \\
\hline HT krisis & $45.255 \pm 58.074$ & $156.686 \pm 111.170$ & $145.600 \pm 75.145$ & $37.000 \pm 8.178$ & $62.110 \pm 45.038$ & $5.390 \pm 8.270$ & $4.200 \pm 3.768$ & $456.241 \pm 197.959$ \\
\hline \multicolumn{9}{|c|}{ Dengan Penyakit Penyerta } \\
\hline HT stage 1 & $10.539 \pm 15.937$ & $177.242 \pm 164.179$ & $90.000 \pm 46.188$ & $32.500 \pm 5.000$ & $64.656 \pm 29.142$ & $14.229 \pm 20.886$ & $9.583 \pm 8.780$ & $398.750 \pm 240.542$ \\
\hline HT stage 2 & $18.851 \pm 15.478$ & $135.381 \pm 124.908$ & $139.351 \pm 56.331$ & $37.776 \pm 10.653$ & $70.104 \pm 24.623$ & $65.843 \pm 63.618$ & $18.921 \pm 16.602$ & $486.227 \pm 241.136$ \\
\hline HT krisis & $14.818 \pm 24.037$ & $147.381 \pm 136.526$ & $96.000 \pm 67.676$ & $38.333 \pm 20.548$ & $69.375 \pm 23.198$ & $52.700 \pm 58.041$ & $7.208 \pm 2.683$ & $425.816 \pm 140.898$ \\
\hline \multicolumn{9}{|c|}{ Dengan Penyakit Penyulit } \\
\hline HT stage 1 & $19.560 \pm 29.732$ & $184.460 \pm 111.762$ & $149.750 \pm 60.573$ & $41.429 \pm 11.249$ & $88.903 \pm 20.974$ & $20.792 \pm 20.998$ & $7.917 \pm 3.181$ & $512.810 \pm 152.661$ \\
\hline HT stage 2 & $17.873 \pm 13.549$ & $164.504 \pm 73.750$ & $82.200 \pm 37.315$ & $38.633 \pm 17.560$ & $78.573 \pm 56.575$ & $44.915 \pm 59.177$ & $17.483 \pm 25.591$ & $444.183 \pm 109.162$ \\
\hline HT krisis & $14.354 \pm 11.578$ & $114.173 \pm 92.462$ & $115.714 \pm 67.788$ & $28.214 \pm 6.244$ & $76.277 \pm 9.577$ & $46.167 \pm 44.420$ & $15.464 \pm 24.682$ & $410.364 \pm 80.388$ \\
\hline
\end{tabular}

Keterangan: HT, hipertensi; SD, standar deviasi 
152.661, hipertensi stage 2 sebesar Rp $444.183 \pm$ 109.162 dan hipertensi krisis sebesar Rp $410.364 \pm$ 80.388. Biaya medis langsung kelompok hipertensi stage 1 lebih tinggi dibandingkan dengan kelompok lainnya pada pasien tanpa penyakit penyerta. Hal ini dapat disebabkan pasien pada kelompok hipertensi stage 1 memiliki penyakit penyulit yang memerlukan obat-obatan serta tindakan medis yang lebih banyak dibandingkan kelompok lainnya pada pasien dengan penyakit penyulit yang dibuktikan dari biaya obat lain serta biaya tindakan medis yang lebih tinggi dibandingkan kelompok lainnya.

Tingginya standar deviasi dari semua perhitungan rata-rata biaya merupakan salah satu dari keterbatasan penelitian ini. Hal ini disebabkan karena adanya perbedaan lama perawatan pasien. Meskipun perhitungan rata-rata biaya sudah dibagi dengan lama perawatan (dalam satuan hari) untuk menurunkan bias akibat lama perawatan, namun masih ada faktor lain yang tidak dapat dihindari yaitu bertambahnya jenis obat, penggantian jenis obat, bertambahnya tindakan medis, penunjang dan pelayanan lain yang akan semakin bertambah dengan semakin lamanya perawatan pasien, terutama pada pasien dengan hipertensi stage II dan hipertensi krisis dengan penyakit penyerta maupun penyulit.

\section{Proporsi Biaya Medis Langsung}

Komponen biaya medis langsung pada penelitian ini meliputi biaya obat, ruang perawatan, kunjungan dokter, tindakan, penunjang, dan pelayanan lain (Gambar 2). Komponen biaya terbesar adalah biaya obat yaitu 37,49\% diikuti dengan biaya ruang perawatan $(26,54 \%)$, biaya tindakan $(15,88 \%)$, biaya penunjang $(9,05 \%)$, biaya visite dokter $(8,12 \%)$ dan biaya pelayanan lainnya $(2,91 \%)$.

Persentase biaya obat tersebut lebih tinggi daripada proporsi biaya obat di Amerika Serikat yaitu hanya $10 \%$ dari total biaya terapi (Centers for Medicare and Medicaid Services, 2017) Hal ini dapat disebabkan harga obat di Indonesia yang relatif mahal dibandingkan harga obat di negara lain (Putri et al., 2004). Penyebab lainnya yaitu penggunaan beberapa jenis obat-obatan yang tidak diperlukan oleh pasien sehingga menyebabkan peningkatan biaya obat.

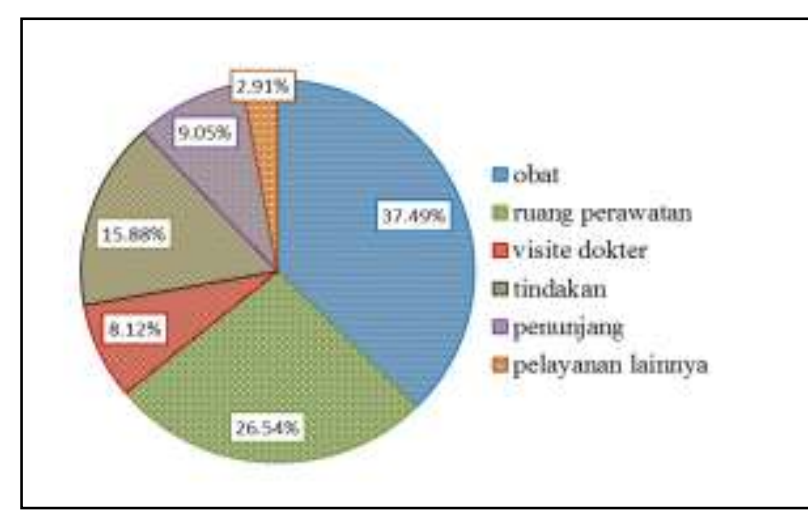

Gambar 2. Proporsi komponen biaya dalam terapi hipertensi awat inap RSUD Praya tahun 2016

\section{KESIMPULAN}

Biaya obat merupakan komponen biaya yang paling berpengaruh dalam biaya langsung medis karena memiliki proporsi biaya terbesar dalam terapi hipertensi. Penggunaan obat yang rasional akan menurunkan biaya terapi pasien hipertensi.

Pada penelitian ini total biaya terapi pasien hipertensi yang diperoleh tidak menunjukkan adanya pola tertentu sehingga diagnosis utama (hipertensi stage I, II dan krisis), adanya penyakit penyerta dan penyakit penyulit tidak mempengaruhi biaya terapi secara signifikan.

Batasan dalam penelitian ini meliputi keterbatasan jumlah data pasien yang memenuhi kriteria penelitian serta kelengkapan data yang diambil. Semakin kecil jumlah sampel yang tersedia dalam satu kelompok, semakin kurang terwakili data kelompok tersebut.

\section{DAFTAR PUSTAKA}

Amira, O. dan N. Okubadejo. 2006. Antihypertensive Pharmacotherapy in a Developing Economy: Pattern, Acquisition Costs and Conformity to International Guidelines in a Tertiary-Care Setting, Journal of Human Hypertension, 20(11):894-897.

Andayani, T.M., 2013, Farmakoekonomi Prinsip dan Metodologi, Yogyakarta, Bursa Ilmu.

Athanasakis, K., Souliotis, K., Tountas, Y., Yfantopoulos, J., Kyriopoulos, J., dan Hatzakis, A., 2014, A Short-Term CostEffectiveness Analysis of Hypertension Treatment in Greece, Hellenic Journal of Cardiology, 55:197-203. 
Benjamin, E.J., Blaha, M.J., Chiuve, S.E., Cushman, M., Das, S.R., Deo, R., de Ferranti, S.D., Floyd, J., Fornage, M., Gillespie, C., Isasi, C.R., Jimenez, M.C., Jordan, L.C., Judd, S.E., Lackland, D., Lichtman, J.H., Lisabeth, L., Liu, S., Longenecker, C.T., Mackey, R.H., Matsushita, K., Mozaffarian, D., Mussolino, M.E., Nasir, K., Neumar, R.W., Palaniappan, L., Pandey, D.K., Thiagarajan, R.R., Reeves, M.J., Ritchey, M., Rodriguez, C.J., Roth, 51 G.A., Rosamond, W.D., Sasson, C., Towfighi, A., Tsao, C.W., Turner, M.B., Virani, S.S., Voeks, J.H., Willey, J.Z., Wilkins, J.T., Wu, J.H.Y., Alger, H.M., Wong, S.S., dan Muntner, P., 2017, Heart Disease and Stroke Statistics 2017 At-a-Glance. American Heart Association.

Centers for Medicare and Medicaid Services, 2017, National Health Expenditure Accounts: Methodology Paper 20167, Center for Medicare and Medicaid Sevices, p. 1-43.

Drummond.M.F., Sculpher, M.J., Torrace, G.W., O'Brien, B.J., Stoddart, G.L., 2005, Methods for the Economic Evaluation of Healthcare Programmes 3rd Edition, Oxford University Press, New York.

Gudmundsdottir, H., Hoieggen, A., Stenehjem, A., Waldum, B., dan Os,I., 2012, Hypertension in Women: Latest Findings and Clinical Implications., Therapeutic Advances in Chronic Disease, 3(3):137-146.

Hage F.G., Mansur, S.J., Xing, D., dan Oparil, S., 2013, Hypertension in Women, Kidney International Supplements, 3(4):352-356.

Joint National Committee, 2004, The Seventh Report of the Joint National Committee on Prevention, Detection, Evaluation, and Treatment of High Blood Pressure Journal of the American Medical Association, 289:25602572.

Kearney, P.M., Whelton, M., Reynolds, K., Whelton, P.K., dan He, J., 2004, Worldwide Prevelance of Hypertension: A Systematic Review, Journal of Hypertensions, 22(1):1119.

Kementerian Kesehatan Republik Indonesia, 2019, Laporan Nasional Riset Kesehatan Dasar 2018, Badan Penelitian dan Pengembangan Kesehatan Kementerian Kesehatan Republik
Indonesia, Jakarta.

Kementerian Kesehatan Republik Indonesia, 2019, Laporan Provinsi Nusa Tenggara Barat Riset Kesehatan Dasar 2018, Badan Penelitian dan Pengembangan Kesehatan Kementerian Kesehatan Republik Indonesia, Jakarta.

Lastra, G., Syed, S., Kurukulasuriya, L.R., Manrique, C., dan Sowers, J.R., 2014, Type 2 Diabetes Mellitus and Hypertension: An Update, Endocrinology and Metabolism Clinics of North America, 43(1):103-122.

Putri, A.E., Siahaan, S., Tjahjono, L., Budiharto, M., Sundari, S., Angkasawati, T., Helmi, R., Ariningrum, R., Tarigan, I., Indriasih, E., 2005, The Prices People Have to Pay for Medicines in Indonesia, National Institute of Health Research and Development Ministry of Health Indonesia in collaboration with WHO Jakarta. p.1-62.

Rahajeng, E.\& Tuminah, S., 2009, Prevalensi Hipertensi dan Determinannya di Indonesia, Majalah Kedokteran Indonesia, 59(12):580587.

Rumah Sakit Umum Daerah Praya, 2016, Profil Rumah Sakit Umum Daerah Praya, Lombok Tengah tahun 2016, Rumah Sakit Umum Daerah, Praya: Indonesia.

Rustiani E, Andrajati R, dan Arsyanti L., 2013, Analisis Penggunaan Obat Antihipertensi di Poliklinik Rawat Jalan Rumah Sakit PMI Bogor: Perbandingan Cost Effectiveness dan Kualitas Hidup Pasien. Jurnal Ilmu Kefarmasian Indonesia. 2(2):209-215.

Setianto, R., Dewi, B. A. dan F. Rosita. 2021. Penyuluhan Swamedikasi Obat Herbal Di PKK Kecamatan Dander Kabupaten Bojonegoro, 4(1):85-93.

Simpanis, S., dan Zamboulis, C., 2008, Arterial Hypertension in Diabetes Mellitus: from Theory to Clinical Practice, Hippokratia, 12(2): 74-80.

Soenarta, A.A., Erwinanto, Mumpuni, A.S.S., Barack, R., Lukito, A.A., Hersunarti, N.N., dan Pratikto, R.S., 2015, Pedoman Tatalaksana Hipertensi pada Penyakit Kardiovaskuler, Perhimpunan Dokter Spesialis Kardiovaskuler Indonesia. 
Tjandrawinata, R. R. 2016. Peran Farmaekonomi dalam Penentuan Kebijakan yang Berkaitan dengan Obat-Obatan', Working Paper of Dexa Medica Group, (January 2016).

Whelton, P.K., Carey, R.M., Aronow, W.S., Casey, D.E.Jr., Collins, K.J., Dennison-Himmelfarb, C., DePalma, S.M., Gidding, S., Jamerson, K.A., Jones, D.W., MacLaughlin, E.J., Muntner, P., Ovbiagele, B., Smith, S.C.Jr., Spencer, C.C., Stafford, R.S., Taler, S.J., Thomas, R.J., Williams, K.A.Sr., Williamson, J.D., dan Wright, J.T.Jr., 2017， 2017 ACC/AHA/

AAPA/ABC/ACPM/AGS/APhA/ASH/ASPC/ NMA/PCNA Guideline for the Prevention, Detection, Evaluation, and Management of High Blood Pressure in Adults, Hypertension, p.69-82.

Wijayanti, N.W., Mukaddas, A., dan Tandah, M.R., 2016, Analisis Efektifitas Biaya Pengobatan Kombinasi Amlodipin Furosemid Dibandingkan dengan Kombinasi Amlodipin Bisoprolol pada Pasien Hipertensi Rawat Jalan di RSUD Undata Palu Periode AgustusOktober tahun 2014, Online Jurnal of Natural Science, 5(1):101-110. 